\title{
C1q Enhancement of Antibody-dependent Granulocyte-mediated Killing of Nonphagocytosable Targets In Vitro
}

\author{
Atsuo Hamada, Joshua Young, Richard A. Chmielewski, and Bruce M. Greene \\ Department of Medicine, Case Western Reserve University and University Hospitals of Cleveland, Cleveland, Ohio 44106
}

\begin{abstract}
A possible role for $\mathrm{Clq}$ in antibody-dependent granulocytemediated killing of nonphagocytosable targets was investigated utilizing IgG-dependent granulocyte cytotoxicity directed against microfilariae of Dirofilaria immitis. Granulocyte-mediated killing of microfilariae is enhanced by addition of fresh serum. Lack of $\mathrm{C} 4$ did not significantly reduce the observed increase in cytotoxicity. The addition of highly purified monomeric human $\mathrm{Clq}(0.2 \mu \mathrm{g} / \mathrm{ml})$ in the presence of immune IgG resulted in a two- to fivefold enhancement of killing $(P<0.025)$. C1q enhancement of killing occurred in the absence of fluid-phase IgG, but killing was significantly less than when both fluid-phase IgG and C1q were present. The effect of C1q was inhibited by the addition of solubilized type I collagen (44-92\% inhibition of killing, $P<0.05)$. Significant ${ }^{125} \mathrm{I}-\mathrm{C} 1 \mathrm{q}$ binding to microfilariae occurred only in the presence of immune IgG. In addition, $\mathrm{Clq}$ in concentrations ranging from 0.5 to $2.0 \mu \mathrm{g} / \mathrm{ml}$ resulted in a dose-dependent increase in binding of ${ }^{125}$ I-immune IgG to microfilariae. Finally, when purified C1q was added to preopsonized, washed microfilariae, granulocyte production of superoxide was increased from $0.25 \pm 0.07$ to $0.68 \pm 0.07 \mathrm{~nm} / 10^{6}$ cells $\cdot 10 \mathrm{~min}(P<0.01)$. These results describe a novel functional role for $\mathrm{Clq}$ in enhancement of antibody-dependent cellular cytotoxicity towards nonphagocytosable targets.
\end{abstract}

\section{Introduction}

During antibody-dependent activation of the classical pathway, Clq, a subcomponent of the first component of complement, serves as the recognition subunit that binds to the $\mathrm{C} 2$ domain of IgG or C4 domain of IgM. Clq has a molecular weight of 410,000 , and consists of a collagenous stalk and six protruding strands which terminate in globular heads (1). The immunoglobulin attachment site resides in the globular heads, while binding of $\mathrm{C} 1 \mathrm{r}$ and $\mathrm{C} 1 \mathrm{~s}$ occurs on the collagenous stalk. Within native $\mathrm{Cl}, \mathrm{Clq}$ is complexed to the proenzyme $\mathrm{Cl}_{2} \mathrm{Cl}_{2}$, which is converted into an activated form after binding of $\mathrm{Clq}$ to appropriate structures such as immune complexes. Activated $\mathrm{Cl}_{2} \mathrm{Cls}_{2}$ cleaves $\mathrm{C} 4$ and $\mathrm{C} 2$, which leads to $\mathrm{C} 3$ cleavage and subsequent activation of the remainder of the complement cascade. The pivotal role of $\mathrm{Clq}$ in classical

Address reprint requests to Dr. Greene, Division of Geographic Medicine, Department of Medicine, University Hospitals, Cleveland, $\mathrm{OH}$ 44106.

Received for publication 29 August 1986 and in revised form 4 February 1988.

J. Clin. Invest.

(c) The American Society for Clinical Investigation, Inc.

0021-9738/88/09/0945/05 $\$ 2.00$

Volume 82, September 1988, 945-949 pathway activation is apparent in individuals who lack this component and who have repeated episodes of bacterial infections and severe skin disease (2).

Recently, a number of reports have demonstrated that $\mathrm{Clq}$ binds to peripheral blood leukocytes and other mammalian cells by way of specific cell surface receptors (3-12). Binding to blood leukocytes was found to be through the collagenous stalk of the Clq molecule (8). Further studies have demonstrated that $\mathrm{Clq}$ bound to nonphagocytosable particles, when presented to granulocytes in suspension, results in stimulation of an oxidative burst. This indicates that the leukocyte $\mathrm{Clq}$ receptor may provide a means for activation of cytotoxic mechanisms (13). In addition, it has recently been demonstrated that adherent mononuclear phagocytes are stimulated by surface-bound $\mathrm{Clq}$ and manifest increased Fc receptormediated phagocytosis (14). The potential importance of cell surface receptors for $\mathrm{Clq}$ is underscored by the observation that after binding of $\mathrm{Cl}$ to an activating substance, $\mathrm{C} 1 \mathrm{r}$ and $\mathrm{Cls}$ are actively disassociated $(15,16)$, thereby exposing monomeric $\mathrm{Clq}$ bound to the activating substance.

We have investigated the possibility that $\mathrm{Clq}$ may play a role in cellular killing of nonphagocytosable targets. We have previously found that $\mathrm{Clq}$ appears to enhance eosinophil-mediated killing of schistosomula of Schistosoma mansoni (17). The model system which we have employed here is killing of microfilariae of Dirofilaria immitis by dog granulocytes (18, 19). In this experimental system, microfilariae are killed by granulocytes only in the presence of specific immunoglobulin directed against the surface of the parasite. The results of the present studies show that $\mathrm{Clq}$ binds to IgG on the surface of the parasite and enhances antibody-dependent killing of these nonphagocytosable targets. The mechanism appears to involve both stimulation via the $\mathrm{Clq}$ receptor on granulocytes and enhancement of IgG binding, thus defining a new functional role for $\mathrm{Clq}$.

\section{Methods}

Microfilariae and granulocytes. Venous blood was obtained from dogs infected with Dirofilaria immitis in the patent microfilaremic phase and microfilariae were isolated as previously described (18).

Granulocyte cell populations were obtained from normal dogs by Ficoll-diatrizoate (Pharmacia Fine Chemicals, Piscataway, NJ) sedimentation as previously described (18). Residual red blood cells were lysed by brief exposure to distilled water.

Adherence and killing assays. Microfilariae (30-50) in $0.1 \mathrm{ml} \mathrm{min-}$ imal essential medium (MEM) were added to wells of flat-bottomed microtiter plates in quadruplicate as previously described (18), and were counted before the addition of cells. All sera used in experiments assessing killing were heat-inactivated $\left(56^{\circ} \mathrm{C}\right.$ for $\left.30 \mathrm{~min}\right)$ and used in a final dilution of $1: 8$ unless indicated otherwise. Cells were added in a volume of $0.05 \mathrm{ml}$ at a concentration of 400,000 per well to obtain a total volume of $0.2 \mathrm{ml}$. Plates were incubated in a $\mathrm{CO}_{2}$ incubator at $37^{\circ} \mathrm{C}$ for $18 \mathrm{~h}$. In comparing results of experiments in which maximal 
killing varied markedly from experiment to experiment, killing percentages were transformed to logarithms for statistical analysis using a paired $t$ test. In experiments to test the effect of collagen, type I calf skin collagen (Calbiochem-Behring Corp., La Jolla, CA) was solubilized in $0.5 \mathrm{M}$ acetic acid, dialyzed against solutions of gradually increasing $\mathrm{pH}$ to $\mathrm{pH}$ 7.4. Finally, the collagen was dissolved in Hanks' balanced salt solution (HBSS, K. C. Biologicals, Lenexa, KS) pH 7.4. Cells were preincubated in collagen in HBSS, $1.5 \mathrm{mg} / \mathrm{ml}$, pH 7.4 for $30 \mathrm{~min}$ on ice, washed once in HBSS, and suspended in MEM (K. C. Biologicals) plus $375 \mu \mathrm{g} / \mathrm{ml}$ collagen. Control cells underwent the same preincubation steps in the absence of collagen. Monoclonal antibodies against neutrophil Fc receptors (3G8, a gift from Dr. M. Berger, and antihuman Leu-11b) were obtained from New England Nuclear (Boston, $\mathrm{MA}$ ) and Becton, Dickinson \& Co. (Mountain View, CA) respectively. They were used at $\sim$ 1:100 final dilution. Binding of anti-Fc receptor antibody to canine granulocytes was confirmed by fluorescence microscopy using anti-human Leu-1 $1 \mathrm{a}$ antibody and anti-Leu- $11 \mathrm{~b}$ antibody followed by fluorescein-labeled goat anti-mouse IgM antibody (Becton, Dickinson \& Co.)

Serum fractionation for isolation of IgM and IgG. IgM purification was as previously described (18). For isolation of IgG, immune serum (IS), ${ }^{1}$ obtained $\sim 2 \mathrm{yr}$ after documented spontaneous clearing of microfilaremia from a dog that had patent infection with high levels of circulating microfilariae (19), or normal dog serum (NDS) was dialyzed against buffer consisting of $0.02 \mathrm{M}$ potassium phosphate, $\mathrm{pH}$ 8.0. This serum was then applied to an Affi-Gel Blue DEAE column (BioRad Laboratories, Richmond, CA). Absorbance was read at $280 \mathrm{~nm}$ and those fractions comprising a peak were pooled and precipitated using 50\% saturated ammonium sulfate. This concentrated sample was then dialyzed twice against HBSS. The resulting IgG fraction was assayed for purity by SDS-polyacrylamide gel electrophoresis (SDSPAGE). For use in the killing assay, IgG was added to each well in a final concentration of $300-360 \mu \mathrm{g} / \mathrm{ml}$.

Immunofluorescent localization of C3. Microfilariae of D. immitis were incubated in $25 \% \mathrm{NDS}$, or IS in MEM for $1 \mathrm{~h}$ at $37^{\circ} \mathrm{C}$, followed by washing three times. FITC-conjugated antisera to dog C3 (Cappel Laboratories, Cochranville, PA) was added at a final dilution of $1: 8$ and tubes were incubated at $4^{\circ} \mathrm{C}$ for $30 \mathrm{~min}$. The microfilariae were then washed three times and were examined for fluorescence.

C4-deficient guinea pig serum. A breeding colony of C4-deficient guinea pigs was obtained through the courtesy of Drs. E. J. Brown and M. M. Frank, National Institute of Allergy and Infectious Diseases, Bethesda, MD.

Clq isolation. Clq was purified by the method described by Tenner et al. (20). In brief, fresh normal human serum was made $5 \mathrm{mM}$ in EDTA, and was applied to a Bio-Rex 70 (Bio-Rad Laboratories) column. The column was then washed with a buffer consisting of $102 \mathrm{mM}$ $\mathrm{NaCl}, 2 \mathrm{mM}$ EDTA, $50 \mathrm{mM}$ sodium phosphate, $\mathrm{pH} 7.3$, and Clq was eluted by application of a linear gradient of increasing ionic strength using a final buffer consisting of $300 \mathrm{mM} \mathrm{NaCl}, 2 \mathrm{mM}$ EDTA, $50 \mathrm{mM}$ sodium phosphate, $\mathrm{pH}$ 7.3. The major protein peaks were precipitated with $33 \%$ saturated ammonium sulfate, then subjected to gel chromatography over a Bio-Gel A5M (Bio-Rad Laboratories) column. The initial protein peak was precipitated with $33 \%$ saturated ammonium sulfate. The presence of $\mathrm{Clq}$ was established by Ouchterlony gel diffusion using goat anti-human Clq (Atlantic Antibodies, Scarborough, ME). Purity was assessed by SDS-PAGE.

To test whether $\mathrm{Clq}$ remained monomeric under the experimental conditions utilized, ${ }^{125} \mathrm{I}-\mathrm{Clq}$ was suspended in MEM plus 5\% BSA and filtered over a Bio-Gel A5M column. Molecular weight standards (Pharmacia Fine Chemicals) included thyroglobulin $(669,000)$, catalase $(232,000)$, and aldolase $(158,000)$. The radiolabeled Clq eluted in a symmetrical peak between thyroglobulin and catalase, and thus indicated nonaggregation of the Clq.

1. Abbreviations used in this paper: GPS, guinea pig serum; IS, immune serum; NDS, normal dog serum.
Binding of ${ }^{125} \mathrm{I}-\mathrm{Clq}$ or ${ }^{125} \mathrm{I}-\mathrm{IgG}$ to microfilariae. Radioiodination of purified human Clq and immune $\operatorname{dog}$ IgG was carried out by the lactoperoxidase-glucose oxidase method as described by Tenner et al. (20).

${ }^{125} \mathrm{I}-\mathrm{Clq}(5 \mu \mathrm{g} / \mathrm{ml})$ was mixed with 100 microfilariae in the presence or absence of $200 \mu \mathrm{g} / \mathrm{ml}$ purified IgG from IS or NDS in a total volume of $500 \mu \mathrm{l}$ in MEM with $1 \%$ ovalbumin, and incubated for $1 \mathrm{~h}$ at $37^{\circ} \mathrm{C}$. After the incubation, the mixture was pelleted by centrifugation, washed once gently, and the radioactivities of the pellets were counted. Nonspecific binding (background) was measured by incubation of ${ }^{125} \mathrm{I}-\mathrm{Clq}$ without microfilariae and IgG. Experimental values were corrected by subtraction.

${ }^{125} \mathrm{I}-\mathrm{IgG}(10 \mu \mathrm{g} / \mathrm{ml})$ and 100 microfilariae were reacted in MEM with $1 \%$ ovalbumin with varying concentrations of $\mathrm{Clq}$ in the range $0.1-2.0 \mu \mathrm{g} / \mathrm{ml}$ or medium, total volume $500 \mu \mathrm{l}$. Incubation and counting were as described above.

Superoxide production. The production of superoxide by neutrophils was measured by reduction of cytochrome $c(21)$. Neutrophils were obtained using the Ficoll-diatrizoate method using HBSS without phenol red, $\mathrm{Ca}^{2+}, \mathrm{Mg}^{2+}$. As a final step, cells were suspended in HBSS without phenol red, with $\mathrm{Ca}^{2+}$ and $\mathrm{Mg}^{2+}$. Microfilariae were preincubated in $1: 9$ concentration of heat-inactivated IS $\left(56^{\circ} \mathrm{C}\right.$ for $\left.\frac{1}{2} \mathrm{~h}\right)$ at $37^{\circ} \mathrm{C}$ for $\frac{1}{2} \mathrm{~h}$, and then washed twice with HBSS. 1-ml spectrophotometer cuvettes were made to contain $1.0 \times 10^{6}$ neutrophils and 1,000 microfilariae and brought to a total volume of $990 \mu \mathrm{l}$ in HBSS with cytochrome $c$ (Sigma Chemical Co., St. Louis, MO) $0.6 \mathrm{mg} / \mathrm{ml} .10 \mu \mathrm{l}$ of the appropriate $\mathrm{Clq}$ solution was added to each cuvette. As a positive control, one cuvette received $10 \mu \mathrm{l}$ of a $0.01 \mathrm{mg} / \mathrm{ml}$ solution of phorbol myristate acetate (Sigma) in HBSS. OD 550 was measured every 2 min. Cuvettes were agitated immediately before each reading. In experiments designed to quantify superoxide production, the incubation was carried out in separate tubes containing the same materials, but aliquots of $0.267 \mathrm{ml}$ were aspirated at 10-min intervals and spun at $400 \mathrm{~g}$ for $10 \mathrm{~min}$, and the absorbance at $550 \mathrm{~nm}$ was read in the supernatant. $\Delta E_{\mathrm{mM}}$ for cytochrome $c$ was taken to be 18.5 (22). To test for an effect of superoxide dismutase, $20 \mu \mathrm{l}$ of HBSS containing both 1 and 0.1 $\mathrm{mg} / \mathrm{ml}$ superoxide dismutase (Sigma Chemical Co.) was added to the $2-\mathrm{ml}$ reaction mixture.

\section{Results}

Effect of Clq on in vitro killing of microfilariae. Microfilariae incubated with granulocytes in the presence of immune serum demonstrated significant enhancement of killing with the addition of fresh guinea pig serum (GPS) to the system (Table I). However, the absence of C4 (in C4-deficient GPS) did not abolish the fresh serum enhancement of killing (Table I). In two separate experiments, examination of microfilariae by fluorescence microscopy after incubation with heat-inactivated immune serum or IgM (tested because IgM does not activate the alternative pathway) and whole GPS showed surface deposition of $\mathrm{C} 3$, while none was seen with either source of antibody when C4-deficient GPS was used.

To test the possibility that partial activation of the classical pathway leading to generation of monomeric $\mathrm{Clq}$ may account for some of the observed fresh serum effect, Clq was purified from human serum and added to the killing system. In these experiments, the effect of exogenous serum factors was minimized by the use of $5 \%$ albumin, in place of whole serum, to preserve cellular and microfilarial integrity. Clq was added in a final concentration of $0.2 \mu \mathrm{g} / \mathrm{ml}$ to wells containing purified IgG. In four separate experiments, there was a two- to fivefold augmentation of microfilarial killing with the addition of purified Clq to the system (Table II) $(P<0.025$, paired $t$ test). This degree of augmentation was comparable to that seen 
Table I. Enhancement of Granulocyte-mediated Antibodydependent Killing of Microfilariae Incubated with IS (1:8) and to Which Fresh GPS or Fresh GPS Deficient in C4 Was Added

\begin{tabular}{lcccccc}
\hline \multirow{6}{*}{\multicolumn{1}{c}{ GPS }} & 1 & 2 & 3 & 4 & 5 & Significance* \\
\cline { 2 - 6 } & & & $\%$ & & & \\
& & & & & & \\
Heat-inactivated & $65 \pm 6^{\ddagger}$ & $80 \pm 2$ & $23 \pm 7$ & $75 \pm 7$ & $47 \pm 14$ & - \\
Fresh & $90 \pm 4$ & $96 \pm 5$ & $60 \pm 13$ & $98 \pm 2$ & $67 \pm 15$ & $<0.005$ \\
C4-deficient & $92 \pm 2$ & $84 \pm 7$ & $88 \pm 9$ & $94 \pm 5$ & $95 \pm 6$ & $<0.05$
\end{tabular}

* Probability of no significant difference when compared to the results with heat-inactivated GPS, paired $t$ test.

${ }^{\ddagger}$ Mean \pm SEM in quadruplicate wells.

with the addition of whole fresh serum. There was no enhancement of background killing when $\mathrm{Clq}$ was added in the absence of immunoglobulin. In two experiments, heating to $56^{\circ} \mathrm{C}$ for 30 min completely abrogated the observed Clq effect, while heating to $47^{\circ} \mathrm{C}$ had no effect (data not shown).

In experiments designed to test whether $\mathrm{Clq}$ binding to IgG on the surface of microfilariae, in the absence of fluidphase IgG, is associated with enhancement of killing, microfilariae were first preopsonized with IgG and washed. In three experiments, the addition of $\mathrm{Clq}$ consistently resulted in slight, but significant, increases in killing of preopsonized microfilariae $(10.9 \pm 5.0 \%$ vs. $6.3 \pm 3.6 \%$ killing, $P<0.01)$. However, the presence of fluid-phase IgG is required for optimal killing when $\mathrm{Clq}$ is added, as evidenced by two separate experiments which showed that the killing in the presence of $\mathrm{Clq}$ and IgG $(16.8 \pm 6.6 \%)$ was significantly higher than with preopsonized microfilariae which had been washed prior to addition of $\mathrm{Clq}(4.7 \pm 1.8 \%)(P<0.001)$.

Binding of ${ }^{125} \mathrm{I}-\mathrm{Cl}$ q to IgG-coated microfilariae. ${ }^{125} \mathrm{I}-\mathrm{Clq}(5$ $\mu \mathrm{g} / \mathrm{ml}$ ) was incubated with microfilariae in the presence of normal dog or immune dog IgG. In the presence of immune $\operatorname{dog} \mathrm{IgG}$, binding of radiolabeled $\mathrm{Clq}$ was significantly increased (mean percent ${ }^{125} \mathrm{I}-\mathrm{C} 1 \mathrm{q}$ binding $36 \pm 11$ with IS vs. $2 \pm 1$ with normal $\operatorname{dog} \operatorname{IgG}, P<0.025)$. In the presence of immune $\mathrm{IgG}$, the average number of molecules of $\mathrm{Clq}$ bound per microfilaria was $1.3 \times 10^{10}$. Binding of ${ }^{125} \mathrm{I}-\mathrm{Clq}$ in the presence of normal dog IgG was not significantly increased over background.

Table II. Enhancement of Antibody-dependent Granulocytemediated Killing of Microfilariae by Monomeric Clq

\begin{tabular}{cccc}
\hline \multirow{2}{*}{$\begin{array}{c}\text { Experiment } \\
\text { no. }\end{array}$} & \multicolumn{3}{c}{ Components added to the microfilariae-cell mixture } \\
\cline { 2 - 4 } & $\mathrm{Clq}$ & \multicolumn{1}{c}{$\mathrm{IgG}$} & $\mathrm{IgG}+\mathrm{Clq}^{*}$ \\
\hline & & \% killing & \\
1 & $5.0 \pm 3.5^{\ddagger}$ & $3.0 \pm 2.7$ & $13.0 \pm 4.5$ \\
2 & - & $13.2 \pm 8.9$ & $70.3 \pm 6.8$ \\
3 & $4.4 \pm 2.4$ & $15.6 \pm 6.5$ & $35.2 \pm 5.1$ \\
4 & - & $17.2 \pm 7.0$ & $31.7 \pm 9.5$
\end{tabular}

* Killing with added IgG plus $\mathrm{Clq}$ is significantly greater than with IgG alone, $\mathrm{p}<0.025$, paired $\mathrm{t}$ test.

$\mp$ Mean \pm SEM in quadruplicate wells.
The effect of washing after preopsonization on Clq binding was tested in four experiments. There was a 1.6-1.8-fold increase in ${ }^{125} \mathrm{I}-\mathrm{Clq}$ binding $(P<0.001)$ when fluid-phase $\mathrm{IgG}$ was present as compared with microfilariae that had been washed and kept free of fluid-phase IgG.

Collagen effect on Clq-enhanced killing. To test the possibility that $\mathrm{Clq}$ attached to microfilariae might bind to granulocytes via the collagenous portion of the molecule and thereby enhance killing, the effect of type I collagen on C1q enhancement of killing was tested. When cells were preincubated in type I collagen, there was a 44-92\% inhibition of killing in three separate experiments $(P<0.05)$. Collagen had no significant effect on baseline killing in the absence of added Clq (data not shown).

Effect of antibody to Fc receptor on killing. The possibility that $\mathrm{Clq}$ is acting independently of the granulocyte Fc receptor was examined using monoclonal antibodies specific for $\mathrm{Fc}$ receptors. When monoclonal antibody to the neutrophil Fc receptor was added to the killing system, there was a significant reduction in IgG-mediated killing (Table III). With the addition of $\mathrm{Clq}$, killing was significantly enhanced over IgG alone despite the presence of anti-Fc receptor antibodies (Table III).

Binding of ${ }^{125}$ I-immune IgG to microfilariae. A second possible mechanism for the observed $\mathrm{Clq}$ effect, enhancement of IgG binding to the target, was examined using ${ }^{125} \mathrm{I}$-labeled IgG. Microfilariae were incubated in medium containing $10 \mu \mathrm{g} / \mathrm{ml}$ ${ }^{125} \mathrm{I}-\mathrm{IgG}$ and $-\mathrm{Clq}$ in concentrations in a range of $0.1-2.0$ $\mu \mathrm{g} / \mathrm{ml}$. Binding of radiolabeled immune $\mathrm{IgG}$ to microfilariae was increased in a dose-dependent fashion by the addition of Clq (Fig. 1). In each experiment, there was a pronounced increase in ${ }^{125} \mathrm{I}-\mathrm{IgG}$ binding to microfilariae in the concentration range of $0.1-0.2 \mu \mathrm{g} / \mathrm{ml} \mathrm{Clq}$, with a slight further increase at a concentration of $2.0 \mu \mathrm{g} / \mathrm{ml}$. The increase in ${ }^{125} \mathrm{I}-\mathrm{IgG}$ binding was significant at each $\mathrm{Clq}$ concentration tested $(P$ $<0.025)$.

Clq stimulation of superoxide production. To examine a possible stimulatory effect of $\mathrm{Clq}$ attached to $\mathrm{IgG}$ opsonized targets, monomeric $\mathrm{Clq}$ was added to granulocytes and preopsonized, washed microfilariae. Superoxide production by exposed granulocytes was measured by reduction of cytochrome $c$. In three separate experiments to define superoxide

Table III. Effect of Monoclonal Antibody against Neutrophil Fc Receptor (FcAb) on IgG-mediated Killing in the Presence and Absence of Added Clq

\begin{tabular}{ccc}
\hline & \multicolumn{2}{c}{ Experiment no. } \\
\cline { 2 - 3 } $\begin{array}{c}\text { Components added to microfilariae } \\
\text { plus granulocytes in killing assays* }\end{array}$ & 1 & 2 \\
\hline & \multicolumn{2}{c}{$\%$} \\
IgG + Clq & $21 \pm 6$ & $100 \pm 0$ \\
IgG + Clq + FcAb & $13 \pm 0$ & $90 \pm 4$ \\
IgG & $6 \pm 8$ & $97 \pm 4$ \\
IgG + FcAb & $3 \pm 4$ & $15 \pm 15$ \\
Clq & $6 \pm 4$ & $5 \pm 4$
\end{tabular}

* Microfilariae and cells plus 5\% BSA were incubated with the components listed as described in Methods. Experiment 1 was performed using 3G8 and experiment 2 with anti-human Leu-llb antibody.

${ }^{\ddagger}$ Killing with IgG $+\mathrm{Clq}+\mathrm{FcAb}$ is significantly greater than with $\mathrm{IgG}+\mathrm{FcAb}($ no Clq),$P<0.05$. 


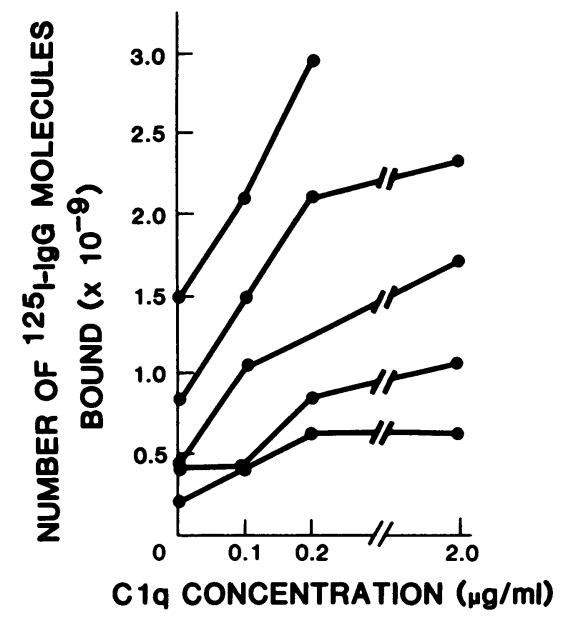

Figure 1. Enhancement of binding of ${ }^{125} \mathrm{I}$-immune IgG to microfilariae by the addition of monomeric Clq. Radiolabeled immune IgG was added to microfilariae with $\mathrm{Clq}$ in concentrations ranging from 0.1 to $2.0 \mu \mathrm{g} / \mathrm{ml}$ and incubated at $37^{\circ} \mathrm{C}$, and the microfilariae were washed and counted. Data are means of triplicate determinations in each experiment. Binding of ${ }^{125} \mathrm{I}-\mathrm{IgG}$ was significantly increased $(P$ $<0.025$ ) at each concentration of added Clq.

production kinetics, the addition of $\mathrm{Clq}$ in concentrations of $0.002-20 \mu \mathrm{g} / \mathrm{ml}$ resulted in enhanced reduction of cytochrome $c$, with the onset of the change in absorbance consistently showing a lag of 14-20 min from the time of addition of C1q. In three further experiments focusing on the time interval 10-20 min after start of incubation, the amount of superoxide produced by cells exposed to opsonized microfilariae alone was $0.25 \pm 0.07 \mathrm{~nm} / 10^{6}$ cells $\cdot 10 \mathrm{~min}$ as compared with $0.68 \pm 0.07 \mathrm{~nm} / 10^{6}$ cells $\cdot 10 \mathrm{~min}$ in the presence of $0.2 \mu \mathrm{g} / \mathrm{ml}$ Clq $(P<0.01)$. Reduction of cytochrome $c$ was inhibited by the addition of superoxide dismutase, but not boiled superoxide dismutase (data not shown).

\section{Discussion}

The present report suggests a novel functional role for $\mathrm{Clq}$ in the augmentation of granulocyte-mediated antibody-dependent killing of a multicellular, nonphagocytosable target. Fresh serum enhancement of killing even in the absence of $\mathrm{C} 4$ raised the possibility of partial activation of the classical pathway. Further, the disparity between the lack of surface C3 deposition and preservation of the fresh serum effect when C4-deficient serum was used suggested an unusual mechanism. By adding highly purified $\mathrm{Clq}$ to the killing system in the absence of whole serum, it was found that $\mathrm{Clq}$ does enhance antibody-dependent killing of microfilariae. The Clq enhancement of killing is seen only in the presence of antibody against the target, which, as demonstrated in this report, results in binding of the $\mathrm{Clq}$ molecule to the organism. This then appears to augment activation of granulocytes, which presumably accounts for the increased cytotoxicity.

The molecule, which was subsequently termed $\mathrm{Clq}$, was first identified as a component of fresh serum which caused precipitation of soluble aggregated immunoglobulin $(23,24)$. This was later shown to be associated with an $11 \mathrm{~S}$ sedimenting component $(25,26)$. Disassociation of native $\mathrm{C} 1$ by EDTA chelation and chromatographic separation of its three activities led to designation of the high molecular weight constituent $\mathrm{Clq}$, and the other two C1r and C1s (27). It is now clear that Clq initiates classical pathway activation by attaching to IgG, IgM, or other activating substances, which under appropriate conditions leads to stabilization of the $\mathrm{Cl}_{2} \mathrm{C} 1 \mathrm{~s}_{2}$ complex and triggering of $\mathrm{Clr}$ and $\mathrm{C} 1 \mathrm{~s}$ esterase activity and classical pathway activation (1). Initiation of the activating process is dependent on the abundance and physicochemical state of the potential activating substance, and activation is further regulated by $\mathrm{C} 1$ inhibitor (1). Other major immunologic functions for $\mathrm{Clq}$ remain to be defined.

Previous results in the microfilarial killing system utilized here indicated that the neutrophil is the predominant effector cell (18), and that oxidative products of neutrophils possess potent cytotoxic properties toward microfilariae (El Sadr et al., manuscript submitted for publication). The present results indicate that $\mathrm{Clq}$ causes an increase in granulocyte-mediated killing and suggest that two mechanisms may be involved. Of possible relevance in this regard is the report by Tenner and Cooper (13) that monomeric Clq bound to nonphagocytosable latex beads stimulates hexose-monophosphate shunt activity and chemiluminescence by granulocytes. They postulated that particle-bound $\mathrm{Clq}$ interacts with the $\mathrm{Clq}$ receptor on the surface of granulocytes, and that this results in stimulation of metabolic and secretory activity. In the present system, the immunoglobulin requirement implicates initial binding of $\mathrm{C} 1 \mathrm{q}$ to antibody. Inhibition of the C1q effect by solubilized type I collagen and the enhancement of killing even in the presence of anti-Fc receptor antibody suggest that $\mathrm{Clq}$ may be acting in part through its specific receptor on granulocytes, resulting in stimulation and perhaps enhanced binding of cell to target. The fact that microfilariae that had been preopsonized, washed, and then exposed to Clq stimulated increased superoxide production by granulocytes supports this hypothesis. However, enhancement of specific IgG binding to the target organism, as demonstrated in this report, or cross-linking of immunoglobulin molecules by $\mathrm{Clq}$ binding, also may be of major importance. The finding that killing and $\mathrm{Clq}$ enhancement of killing were less when microfilariae were preopsonized and washed before addition of $\mathrm{Clq}$ (as opposed to simultaneous incubation) suggests that a $\mathrm{Clq}$ effect on antibody binding is partially responsible for the effect. In addition, more $\mathrm{Clq}$ is bound to the microfilariae after simultaneous incubation with $\mathrm{IgG}$ and $\mathrm{Clq}$. Of possible relevance in this regard is the previous report that partially purified $\mathrm{Clq}$ increases binding of cold reacting antibodies to human red blood cells (28). Further, it has been suggested that membranebound Clq may function as a cellular receptor for immunoglobulin Fc regions $(12,29)$. The present results suggest that the Clq effect noted here may result from both stimulation of granulocytes via the $\mathrm{Clq}$ receptor and enhancement of $\mathrm{IgG}$ binding to the target.

The previous demonstration of a granulocyte stimulatory role for $\mathrm{Clq}$ was also in a system employing nonphagocytosable targets, C1q-coated latex beads $\sim 15 \mu \mathrm{m}$ in diameter (13). Furthermore, we have demonstrated that $\mathrm{Clq}$ appears to enhance killing of schistosomula of $S$. mansoni (18). It is possible that C1q serves a particularly important function when the target for granulocyte-mediated killing is too large to be ingested (e.g., multicellular parasites, tumor cells, antibodycoated host cells), and killing is therefore dependent on a 
mechanism for stimulating granulocytes to secrete cytotoxic products onto the surface of the target.

\section{Acknowledgments}

The technical assistance of Donata Rechnitzer, Isabel Lewis, and Helen Cicirello and the secretarial support of Pat Amato are gratefully acknowledged.

This work was supported in part by U. S. Public Health Service grants EY-03318 and AI-15351. Animals were provided in part by the U. S.-Japan Cooperative Medical Sciences Program, National Institute of Allergy and Infectious Diseases.

\section{References}

1. Cooper, N. R. 1985. The classical complement pathway: activation and regulation of the first complement component. $A d v$. Immunol. 37:151-216.

2. Berkel, A. I., M. Loos, O. Sanal, F. Ersoy, and O. Yegin. 1981. Selective complete Clq deficiency. Immunol. Lett. 2:263-267.

3. Dickler, H. B., and H. G. Kunkel. 1972. Interaction of aggregated gamma globulin with B lymphocytes. J. Exp. Med. 136:191-196.

4. Sobel, A. T., and V. A. Bokisch. 1975. Receptor for Clq on peripheral human lymphocytes and human lymphoblastoid cells. Fed. Proc. 34:965. (Abstr.)

5. Gupta, R. C., F. C. McDuffie, G. Tappeiner, and R. E. Jordon. 1978. Binding of soluble immune complexes to Raji lymphocytes: role of receptors for complement components, $\mathrm{Clq}$ and $\mathrm{C} 3-\mathrm{C} 3 \mathrm{~b}$. Immunology. 34:751-761.

6. Ghebrehiwet, B., and H. J. Muller-Eberhard. 1978. Lysis of C1q-coated chicken erythrocytes by human lymphoblastoid cell lines. J. Immunol. 120:27-32.

7. Gabay, Y., H. Perlmann, P. Perlmann, and A. T. Sobel. 1979. A rosette assay for the determination of Clq receptor-bearing cells. Eur. J. Immunol. 9:797-801.

8. Tenner, A. J., and N. R. Cooper. 1980. Analysis of receptor-mediated $\mathrm{Clq}$ binding to human peripheral blood mononuclear cells. $J$. Immunol. 125:1658-1664.

9. Tenner, A. J., and N. R. Cooper. 1981. Identification of types of cells in human peripheral blood that bind Clq. J. Immunol. 126:1174-1179.

10. Arvieux, J., A. Reboul, J. Bensa, and M. G. Colomb. 1984. Characterization of the $\mathrm{Clq}$ receptor on human macrophage cell line U937. Biochem. J. 218:547-555.

11. Suba, E. A., and G. Csako. 1976. $\mathrm{Clq}(\mathrm{Cl})$ receptor on human platelets: inhibition of collagen-induced platelet aggregation by $\mathrm{Clq}$ (C1) molecules. J. Immunol. 117:304-309.

12. Bordin, S., W. P. Kolb, and R. C. Page. 1983. Clq receptors on cultured human gingival fibroblasts: analysis of binding properties. $J$. Immunol. 130:1871-1875.

13. Tenner, A. J., and N. R. Cooper. 1982. Stimulation of a human polymorphonuclear leukocyte oxidative response by the $\mathrm{Clq}$ subunit of the first complement component. J. Immunol. 128:2547-2552.

14. Bobak, D. A., T. A. Gaither, M. M. Frank, and A. J. Tenner. 1987. Modulation of FcR function by complement: subcomponent Clq enhances the phagocytosis of IgG-opsonized targets by human monocytes and culture-derived macrophages. J. Immunol. 138:11501156.

15. Ziccardi, R. J., and N. R. Cooper. 1979. Active disassembly of the first complement component, $\mathrm{Cl}$, by $\mathrm{Cl}$ inactivator. J. Immunol. 123:788-792.

16. Sim, R. B., and A. Reboul. 1981. Preparation and properties of human $\mathrm{C} 1$ inhibitor. Methods Enzymol. 80:43-54.

17. Hamada, A., and B. M. Greene. 1987. Clq enhancement of IgG-dependent eosinophil-medicated killing of schistosomula in vitro. J. Immunol. 138:1240-1245.

18. El-Sadr, W. M., M. Aikawa, and B. M. Greene. 1983. In vitro immune mechanisms associated with clearance of microfilariae of Dirofilaria immitis. J. Immunol. 130:428-434.

19. Gbakima, A. A., W. El-Sadr, and B. M. Greene. 1986. Delayed isotype switching in Dirofilaria immitis infection. Trans. R. Soc. Trop. Med. Hyg. 80:305-308.

20. Tenner, A. J., P. H. Lesavre, and N. R. Cooper. 1981. Purification and radiolabeling of human Clq. J. Immunol. 127:648-653.

21. Babior, B. M., R. S. Kipnes, and J. T. Curnutte. 1973. Biological defense mechanisms: the production by leukocytes of superoxide, a potential bactericidal agent. J. Clin. Invest. 52:741-744.

22. Margoliash, E., and N. Frohwirt. 1959. Spectrum of horse-heart cytochrome $c$. Biochem. J. 71:570-572.

23. Heidelberger, M. 1940. A quantitative, absolute method for the estimation of complement (Alexin). Science (Wash. DC). 92:534-535.

24. Heidelberger, M., and M. Mayer. 1942. Quantitative chemical studies on complement or alexin. J. Exp. Med. 75:285-295.

25. Muller-Eberhard, H. J., and H. G. Kunkel. 1961. Isolation of a thermolabile serum protein which precipitates gamma globulin aggregates and participates in immune hemolysis. Proc. Soc. Exp. Biol. Med. 106:291-295.

26. Taranta, A., H. S. Weiss, and E. C. Franklin. 1961. Precipitating factor for aggregated gamma-globulins in normal human sera. Nature (Lond.). 89:239-240.

27. Lepow, I. H., G. B. Naff, E. W. Todd, J. Pensky, and C. F. Hinz, Jr. 1963. Chromatographic resolution of the first component of human complement into three activities. J. Exp. Med. 117:983-1008.

28. Rosse, W. F., T. Borsos, and H. R. Rapp. 1968. Cold-reacting antibodies: the enhancement of antibody fixation by the first component of complement (C'1a). J. Immunol. 100:259-265.

29. Loos, M. 1983. Biosynthesis of the collagen-like Clq molecule and its receptor functions for $\mathrm{Fc}$ and polyanionic molecules on macrophages. Curr. Top. Microbiol. Immunol. 102:1-56. 